Prepared in cooperation with the

Delaware Department of Natural Resources and Environmental Control and the

Delaware Geological Survey

Residence Time, Chemical and Isotopic Analysis of Nitrate in the Groundwater and Surface Water of a Small Agricultural Watershed in the Coastal Plain, Bucks Branch, Sussex County, Delaware

Serentific Investigations Report $2012=5235$

U.S. Department of the Interior
US. Geologitoal singy

U.S. Department of the
TS Geological survey

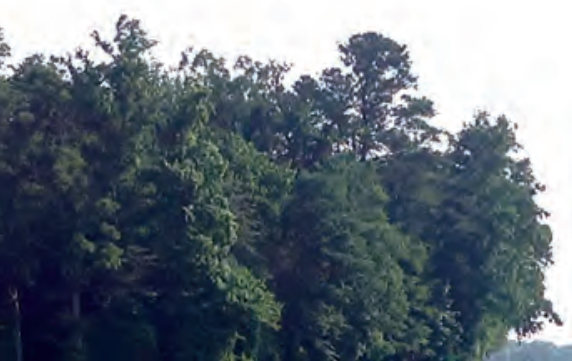

प्रक

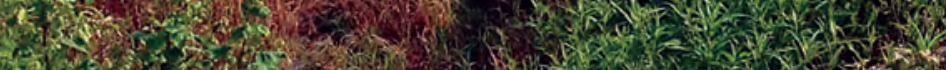


Cover. The Bucks Branch watershed is in a relatively flat, predominantly agricultural setting, and most stream morphology has been channelized. Photograph by John Clune, U.S. Geological Survey. 


\section{Residence Time, Chemical and Isotopic Analysis of Nitrate in the Groundwater and Surface Water of a Small Agricultural Watershed in the Coastal Plain, Bucks Branch, Sussex County, Delaware}

By John W. Clune and Judith M. Denver

Prepared in cooperation with the

Delaware Department of Natural Resources and Environmental Control and the

Delaware Geological Survey

Scientifc Investigations Report 2012-5235 


\section{U.S. Department of the Interior \\ KEN SALAZAR, Secretary \\ U.S. Geological Survey \\ Marcia K. McNutt, Director}

\section{U.S. Geological Survey, Reston, Virginia: 2012}

For more information on the USGS - the Federal source for science about the Earth, its natural and living resources, natural hazards, and the environment, visit http://www.usgs.gov or call 1-888-ASK-USGS.

For an overview of USGS information products, including maps, imagery, and publications, visit http://www.usgs.gov/pubprod

To order this and other USGS information products, visit http://store.usgs.gov

Any use of trade, firm, or product names is for descriptive purposes only and does not imply endorsement by the U.S. Government.

Although this information product, for the most part, is in the public domain, it also may contain copyrighted materials as noted in the text. Permission to reproduce copyrighted items must be secured from the copyright owner.

Suggested citation:

Clune, J.W., and Denver, J.M., 2012, Residence time, chemical and isotopic analysis of nitrate in the groundwater and surface water of a small agricultural watershed in the Coastal Plain, Bucks Branch, Sussex County, Delaware:

U.S. Geological Survey Scientific Investigations Report 2012-5235, 15 p. 


\section{Contents}

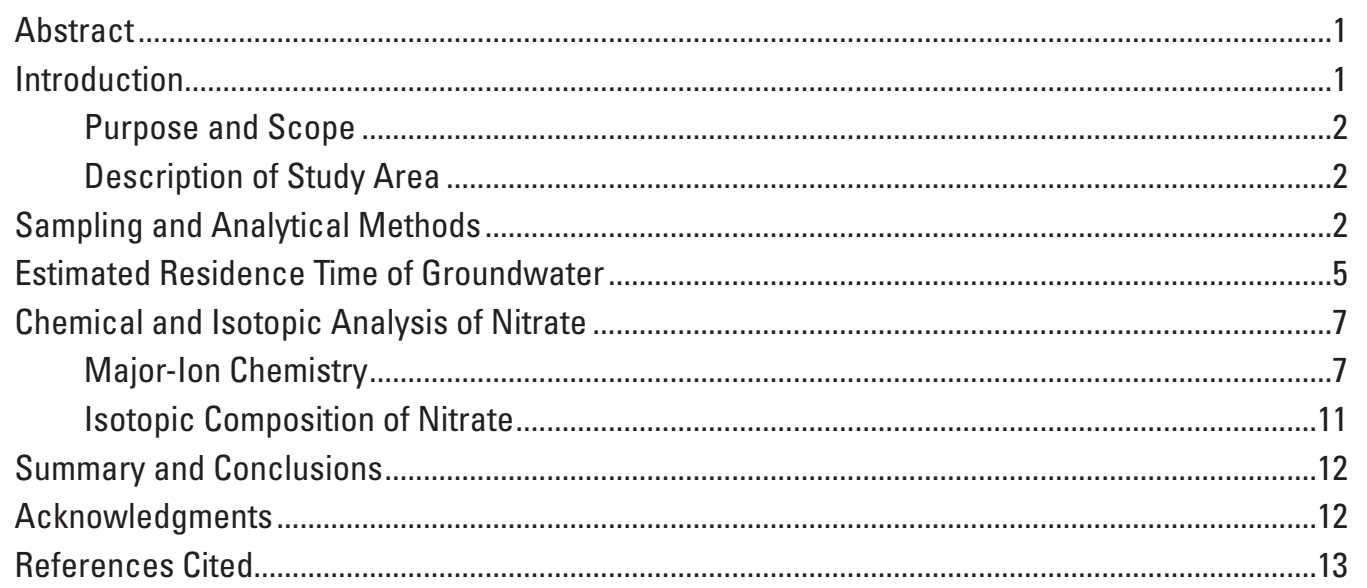




\section{Figures}

1. Map showing location of study area, surface-water sampling sites, and land use in the Bucks Branch watershed, Sussex County, Delaware

2. Aerial photographs of historical agricultural land use in Bucks Branch watershed, Sussex County, Delaware in $(A) 1968$, and $(B) 1997$.

3-4. Graphs showing-

3. Nitrogen inputs from fertilizer, manure, septic, and atmospheric sources in Sussex County, Delaware, 1982-2002. . .4

4. Concentration of silica in relation to the age of groundwater in Bucks Branch watershed, Sussex County, Delaware.

5. Boxplots showing distribution of selected characteristics and constituents in groundwater and surface-water samples, Bucks Branch watershed, Sussex County, Delaware...

6-8. Graphs showing-

6. Concentrations of nitrate in relation to the concentrations of $(A)$ calcium plus magnesium $(\mathrm{Ca}+\mathrm{Mg}),(B)$ potassium plus chloride $(\mathrm{K}+\mathrm{Cl})$, and $(\mathrm{C})$ specific conductance $(\mathrm{SC})$ in groundwater samples collected in Bucks Branch watershed, Sussex County, Delaware, 2011

7. Relative abundance patterns of constituents in samples of $(A)$ groundwater and $(B)$ surface water, and $(C)$ a trilinear diagram of major ions within Bucks Branch watershed, Sussex County, Delaware.

8. Relation of nitrogen isotopes to oxygen isotopes in groundwater and surface water, Bucks Branch watershed, Sussex County, Delaware.

9. Map showing nitrate concentrations and nitrogen-isotope compositions in samples of surface water collected synoptically during high base-flow conditions, Bucks Branch watershed, Sussex County, Delaware, March 2011

\section{Tables}

1. Minimum, median, and maximum values of selected characteristics and constituents in groundwater and surface-water samples collected synoptically in the Bucks Branch watershed, Sussex County, Delaware, spring and summer 2011

2. Chemistry of natural groundwater in the surfical aquifer of Southern

Delaware 


\section{Conversion Factors and Datums}

\begin{tabular}{|c|c|c|}
\hline Multiply & By & To obtain \\
\hline \multicolumn{3}{|c|}{ Length } \\
\hline inch (in.) & 2.54 & centimeter $(\mathrm{cm})$ \\
\hline foot (ft) & 0.3048 & meter $(\mathrm{m})$ \\
\hline mile (mi) & 1.609 & kilometer (km) \\
\hline \multicolumn{3}{|c|}{ Area } \\
\hline acre & 4,047 & square meter $\left(\mathrm{m}^{2}\right)$ \\
\hline acre & 0.004047 & square kilometer $\left(\mathrm{km}^{2}\right)$ \\
\hline square mile $\left(\mathrm{mi}^{2}\right)$ & 2.59 & square kilometer $\left(\mathrm{km}^{2}\right)$ \\
\hline \multicolumn{3}{|c|}{ Volume } \\
\hline gallon (gal) & 3.785 & liter (L) \\
\hline gallon (gal) & 0.003785 & cubic meter $\left(\mathrm{m}^{3}\right)$ \\
\hline \multicolumn{3}{|c|}{ Flow rate } \\
\hline inch per year (in/yr) & 2.54 & centimeter per year $(\mathrm{cm} / \mathrm{yr})$ \\
\hline foot per second (ft/s) & 0.3048 & meter per second $(\mathrm{m} / \mathrm{s})$ \\
\hline
\end{tabular}

Temperature in degrees Fahrenheit $\left({ }^{\circ} \mathrm{F}\right)$ may be converted to degrees Celsius $\left({ }^{\circ} \mathrm{C}\right)$ as follows:

$$
{ }^{\circ} \mathrm{C}=\left({ }^{\circ} \mathrm{F}-32\right) / 1.8
$$

Vertical coordinate information is referenced to the National Geodetic Vertical Datum of 1988 (NGVD 88).

Horizontal coordinate information is referenced to the North American Datum of 1983 (NAD 83).

Elevation, as used in this report, refers to distance above the vertical datum. 



\title{
Residence Time, Chemical and Isotopic Analysis of Nitrate in the Groundwater and Surface Water of a Small Agricultural Watershed in the Coastal Plain, Bucks Branch, Sussex County, Delaware
}

\author{
By John W. Clune and Judith M. Denver
}

\begin{abstract}
Nitrate is a common contaminant in groundwater and surface water throughout the Nation, and water-resource managers need more detailed small-scale watershed research to guide conservation efforts aimed at improving water quality. Concentrations of nitrate in Bucks Branch are among the highest in the state of Delaware and a scientific investigation was performed to provide water-quality information to assist with the management of agriculture and water resources. A combination of major-ion chemistry, nitrogen isotopic composition and age-dating techniques was used to estimate the residence time and provide a chemical and isotopic analysis of nitrate in the groundwater in the surficial aquifer of the Bucks Branch watershed in Sussex County, Delaware. The land use was more than 90 percent agricultural and most nitrogen inputs were from manure and fertilizer. The apparent median age of sampled groundwater is 18 years and the estimated residence time of groundwater contributing to the streamflow for the entire Bucks Branch watershed at the outlet is approximately 19 years. Concentrations of nitrate exceeded the U.S. Environmental Protection Agency drinking-water standard of 10 milligrams per liter (as nitrogen) in 60 percent of groundwater samples and 42 percent of surface-water samples. The overall geochemistry in the Bucks Branch watershed indicates that agriculture is the predominant source of nitrate contamination and the observed patterns in major-ion chemistry are similar to those observed in other studies on the Mid-Atlantic Coastal Plain. The pattern of enrichment in nitrogen and oxygen isotopes $\left(\delta^{15} \mathrm{~N}\right.$ and $\left.\delta^{18} \mathrm{O}\right)$ of nitrate in groundwater and surface water indicates there is some loss of nitrate through denitrification, but this process is not sufficient to remove all of the nitrate from groundwater discharging to streams, and concentrations of nitrate in streams remain elevated.
\end{abstract}

\section{Introduction}

Nitrogen is a common contaminant in groundwater and surface water throughout the Nation (Dubrovsky and others, 2010). Sources of nitrate include atmospheric deposition, municipal and residential wastewater treatment systems, and the widespread agricultural use of commercial fertilizer and manure (Puckett, 1995). Previous studies have shown that elevated concentrations of nitrate in groundwater and surface water are often attributable to urban development or agriculture (Ator and Ferrari, 1997; Mueller and Spahr, 2006; Dubrovsky and others, 2010). Regional assessments and modeling have shown that the predominant impairment to water quality on the Delmarva Peninsula is due to agriculture (Hamilton and others, 1993; Shedlock and others, 1999; Debrewer and others, 2007; Ator and others, 2011). The substantial nitrogen inputs from manure and fertilizer associated with intensive agricultural areas have been reflected in the chemical composition of groundwater in the surficial aquifer of this region (Denver, 1986, 1989). Bucks Branch, a small agricultural watershed in Sussex County, Delaware, has some of the highest measured concentrations of total nitrogen in any stream in the State (Delaware Department of Natural Resources and Environmental Control, 2010) and most of the nitrogen is in the form of nitrate.

Although the association of groundwater and surfacewater chemistry with land use can be indicative of nitrogen sources, more specific investigations have been conducted using chemical, isotopic, and age-dating techniques to provide a better understanding of the nitrogen sources, biogeochemical processes, and the residence time associated with nitrate transport through groundwater. For instance, major-ion chemistry in relation to nitrate concentrations in groundwater has shown a marked contrast between water that recharged the surficial aquifer through areas of agriculture compared to other land 
uses (Denver, 1986, 1989: Hamilton and others, 1993). The nitrogen and oxygen isotopes of nitrate have been used to indicate the sources of nitrogen, and tracing the fractionation of these isotopes can provide evidence of denitrification (Heaton, 1986; Clark and Fritz, 1997; Kendall and McDonnell, 1998; Böhlke, 2003). Age dating of groundwater has also been used successfully in determining the overall residence time of water within aquifers (Busenberg and Plummer, 1992; Dunkle and others, 1993).

Recent approaches to describe temporal changes in the concentrations of nitrate in groundwater have used a combination of the chemical, isotopic, and age-dating techniques (Böhlke and Denver, 1995; Stoner and others, 1997; Denver and others, 2010). The research described in this report builds upon this multidisciplinary approach at a small watershed scale. At this level, the results will serve the needs of resource managers by providing a more practical perspective on the traveltime of groundwater to streams, a detailed understanding of the sources of nitrogen for targeting management efforts, and better quantification of the outcomes of water-quality improvements (National Research Council, 2011; Weller and others, 2010). This study was conducted by the U.S. Geological Survey (USGS) in cooperation with the Delaware Geological Survey (DGS) and the Delaware Department of Natural Resources and Environmental Control (DNREC) and is part of a regional effort to better understand small watershed processes in the Chesapeake Bay watershed.

\section{Purpose and Scope}

The purpose of this report is to present (1) estimated residence times of groundwater, and (2) provide a chemical and isotopic analysis of nitrate in the groundwater of the surficial aquifer and surface-water system for Bucks Branch watershed on the Delmarva Peninsula in Sussex County, Delaware. These objectives were met by the collection of stream-water samples in 2011 during periods when the dominant contribution of streamflow was from groundwater during high (March) and low (August) base-flow conditions, and with the collection of groundwater samples in June 2011. Major-ion chemistry and the nitrogen and oxygen isotopic composition of nitrate in groundwater and stream water during base flow were used to evaluate the potential sources of nitrogen and to describe biogeochemical processes affecting concentrations of nitrate in water. Concentrations of sulfur hexafluoride $\left(\mathrm{SF}_{6}\right)$ and dissolved gases in groundwater, and concentrations of silica in groundwater and surface water were used to determine the apparent age of groundwater in the aquifer and to estimate the average residence time of groundwater discharging to streams.

\section{Description of Study Area}

Bucks Branch drains 7.02 square miles $\left(\mathrm{mi}^{2}\right)$, and is a tributary to the Nanticoke River on the Delmarva Peninsula, which eventually drains into the Chesapeake Bay. The study area is located approximately 32 miles (mi) west of the Atlantic Ocean shoreline in Sussex County, Delaware (fig. 1). The area is underlain by sediments of the Beaverdam Formation that consists mainly of fluvial and estuarine deposits of sand, gravel, silt, and clays (Andres, 1994). The soil is predominantly well-drained sandy loam (U.S. Department of Agriculture, 2012). The unconfined surficial aquifer is approximately 100 feet (ft) thick and the water table is 5 to 10 feet below land surface (Denver, 1986). In this area of the Coastal Plain Physiographic Province, groundwater provides the largest contribution of freshwater flow in streams and is the predominant influence on surface-water quality and the major source of nitrate (Shedlock and others, 1999; Lindsey and others, 2003; Spahr and others, 2010).

Land use is predominantly agricultural, consisting mainly of cropland (90.1 percent) and concentrated animal feeding operations ( 0.8 percent), along with wetland (4.1 percent), residential dwellings ( 2.6 percent), forest (1.9 percent) and other settings ( 0.5 percent) (fig. 1$)$. Most wetlands are located in the headwaters along the main stem of Bucks Branch, where the soils are poorly drained and less suited for agriculture. Agriculture has been primarily poultry production and varieties of row-crop cultivation during the past 50 years (fig. 2). Manure and fertilizer are applied to corn fields from February to April and to fields of small grains from February to March. Corn is planted from April to May and harvested for silage and grain from August through October. The vast majority of nitrogen inputs in this part of Sussex County, Delaware are from manure and fertilizer (fig. 3).

The topography in the Bucks Branch watershed is relatively flat, with elevations that range from 30 to $50 \mathrm{ft}$ above sea level. The local climate provides for a wet season of increased precipitation from April through June, with a mean annual rainfall of 44 inches per year (in/yr), of which approximately 14 inches (in.) recharges the aquifer (Johnston, 1973). The watershed consists of three tributaries where the stream morphology has been extensively altered. Channelization has created steep banks and berms along the streams that are often hydraulically disconnected from flood plains and riparian zones. This channelization and dredging (ditching) of streams affects the nearby water table and impairs the functional properties of the aquatic ecosystem (Williams and others, 2004). The adjacent access roads used for maintaining the ditches reduce canopy cover over the stream channels.

\section{Sampling and Analytical Methods}

Sampling sites included 7 stream locations throughout the watershed (fig. 1), and a random selection of 10 shallow domestic wells (median depth of $63 \mathrm{ft}$ below land surface) screened within the surficial aquifer (locations of homeowners' wells not shown). Streams were sampled synoptically during high (March) and low (August) base flows and groundwater was sampled once in June 2011. The USGS and DNREC 


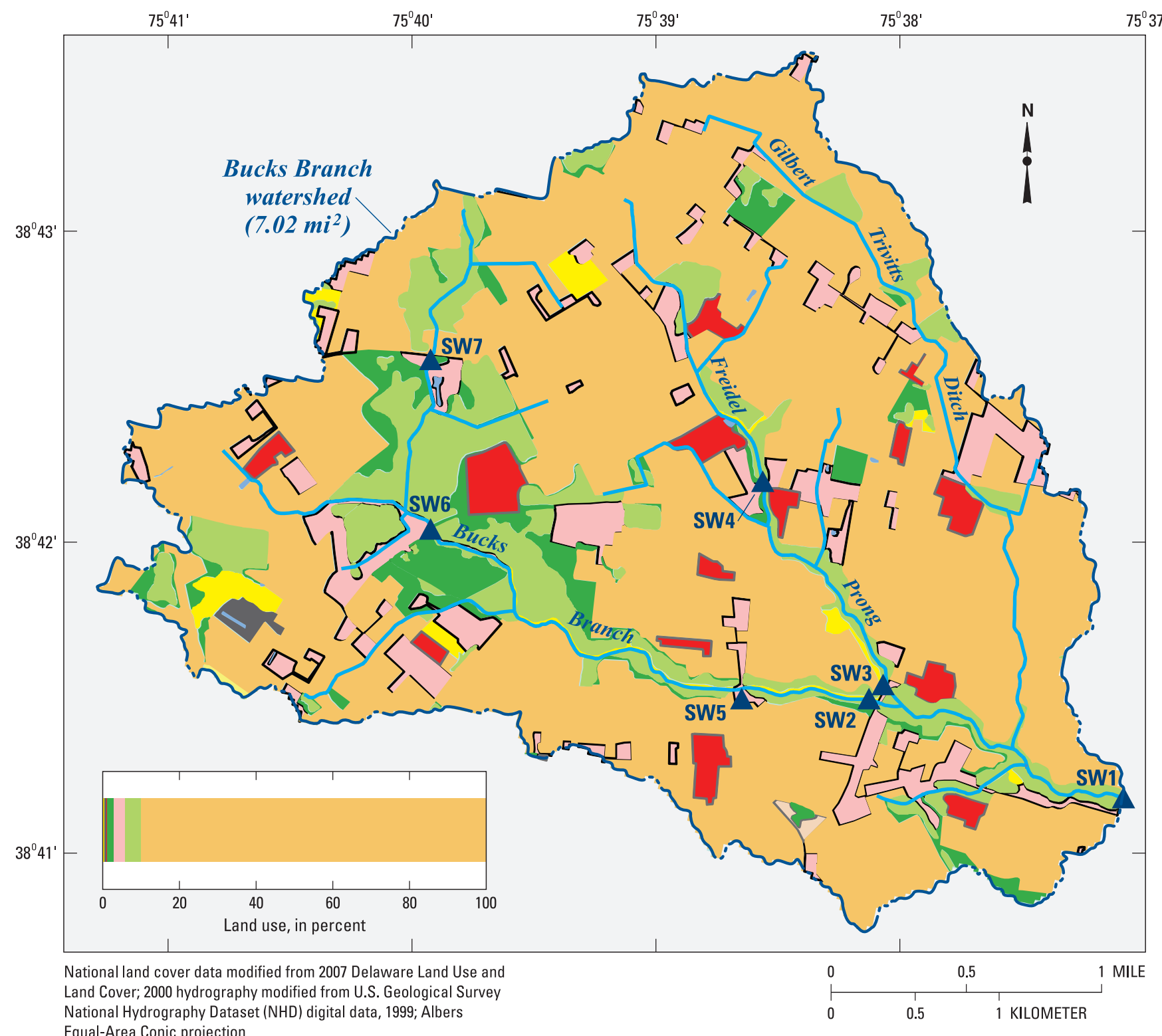

Equal-Area Conic projection

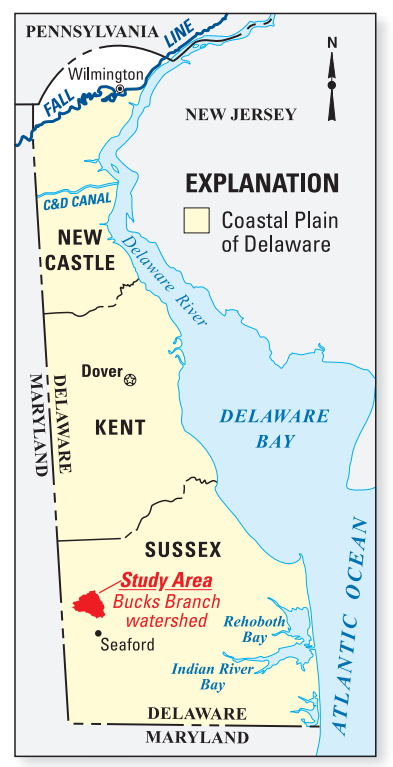

\section{EXPLANATION}

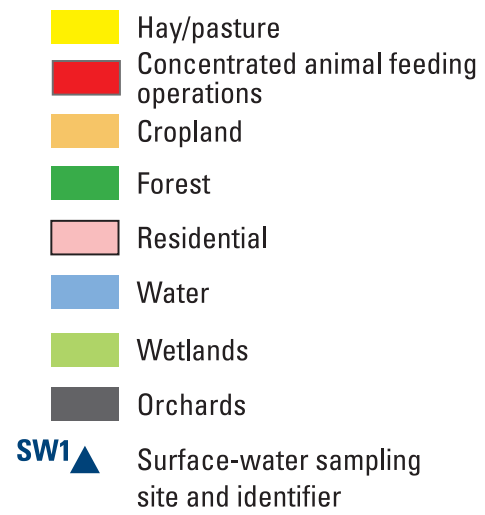

Figure 1. Location of study area, surface-water sampling sites, and land use in the Bucks Branch watershed, Sussex County, Delaware. 


\section{A. 1968}

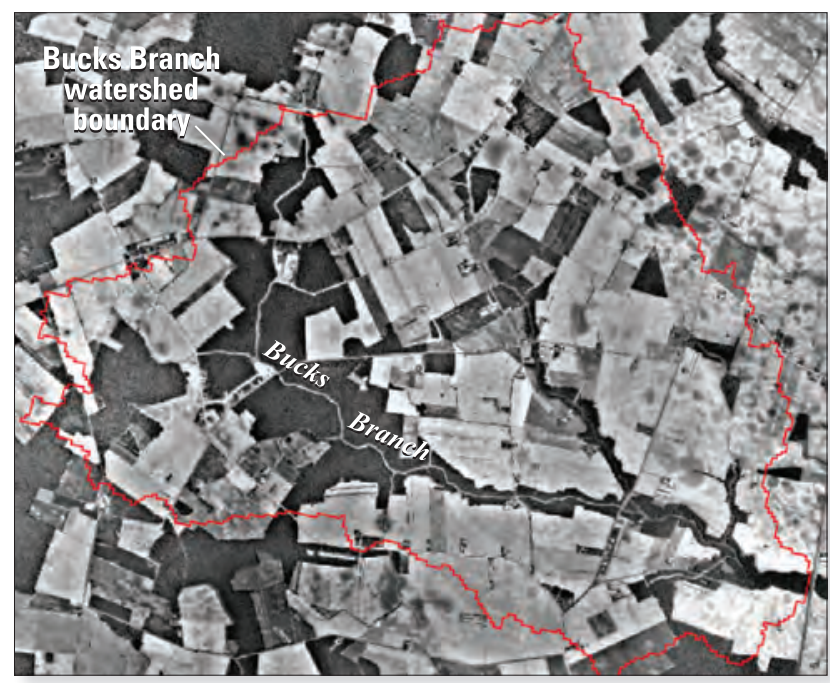

Aerial photograph by Agricultural Stabilization and Conservation Service, 1968
B. 1997

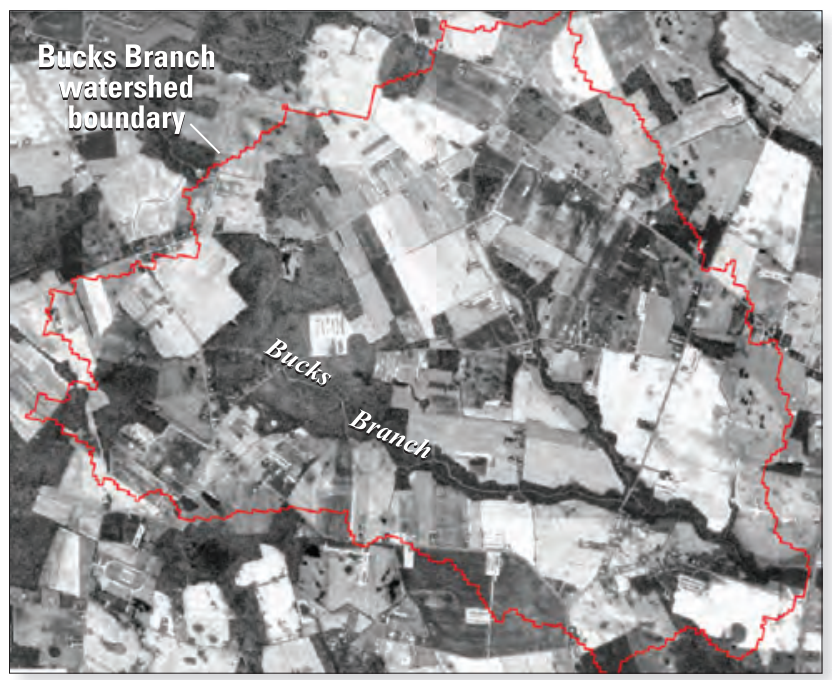

Aerial photograph by Earth Data

(formerly PhotoScience), 1997

Figure 2. Aerial photographs of historical agricultural land use in Bucks Branch watershed, Sussex County, Delaware in $(A)$ 1968, and $(B) 1997$.

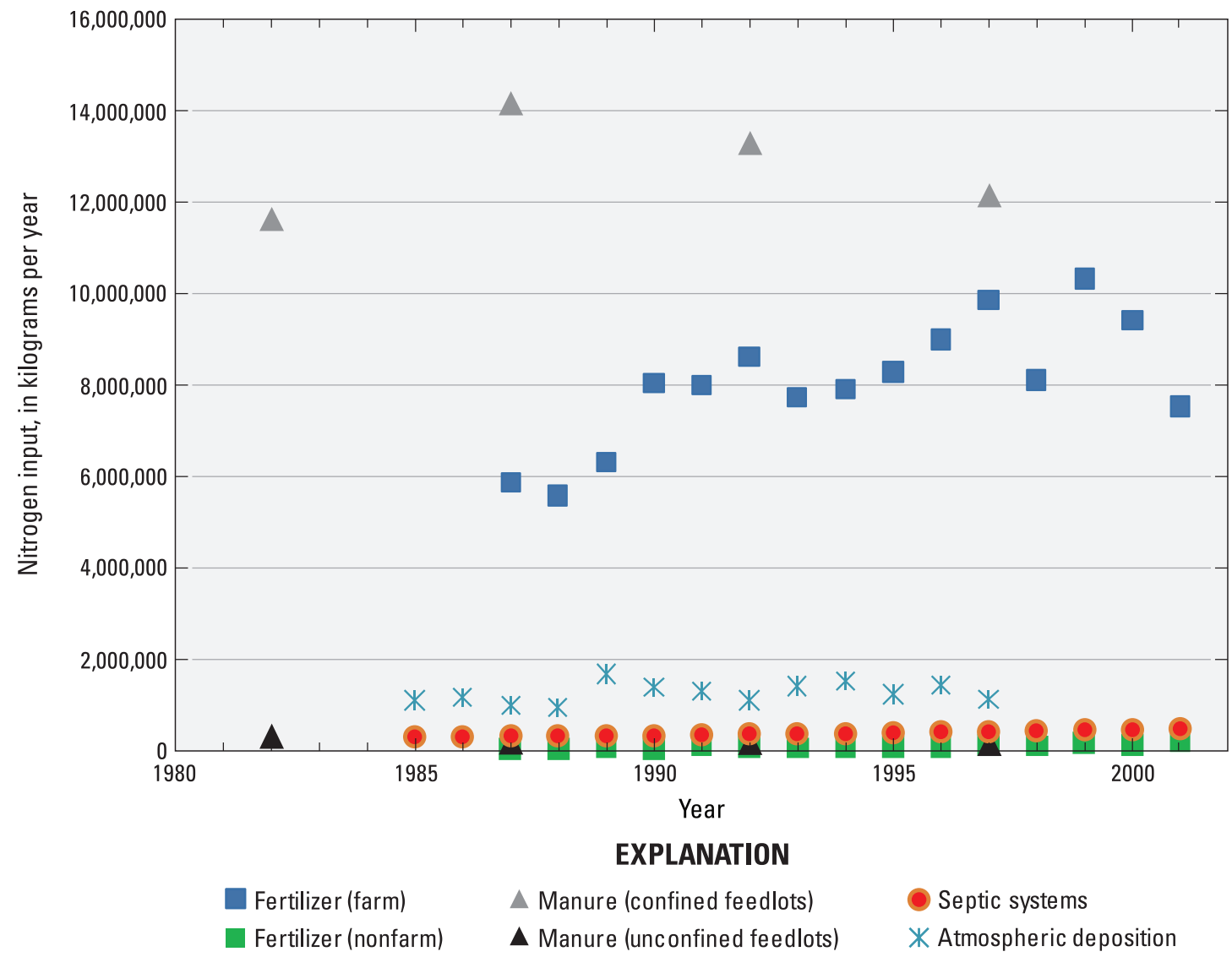

Figure 3. Nitrogen inputs from fertilizer, manure, septic, and atmospheric sources in Sussex County, Delaware, 1982-2002 (Values are based on data from Ruddy and others, 2006; U.S. Bureau of the Census, 1993; and calculations described in Lindsey and others, 2009). 
worked together to perform the data collection and analysis. The USGS collected samples for analysis of isotopes of nitrate at the surface-water sites and sampled groundwater for both isotopes and age dating at the domestic wells. This work was completed in coordination with DNREC scientists from the Division of Water who provided the reconnaissance and landowner permission along with the field collection of groundwater and surface-water samples for analysis of nutrients and major ions.

Groundwater and surface-water samples for the majorion and nutrient analysis were collected following protocols outlined in the USGS National Field Manual (U.S. Geological Survey, variously dated). Groundwater samples were collected using a brass connection to a sampling point (outside spigot) prior to any water treatment. Wells were purged until field parameters $(\mathrm{pH}$, specific conductance, water temperature, and dissolved oxygen) stabilized and the final readings were recorded. Samples were then collected for laboratory analysis of nutrients, major ions, nitrate isotopes, and age dating. Surface-water sampling included field measurements (discharge, $\mathrm{pH}$, specific conductance, dissolved oxygen, and temperature) in which the mean of stabilized readings was taken at six-tenths of the vertical stream depth to represent the average velocity of the water column and provide a homogenous mixture. Isokinetic samples were collected using a depth-integrating vertical sampler and composited in a churn following USGS protocols for equal-width-increment sampling (U.S. Geological Survey, variously dated). Grab samples were collected at the centroid of flow for streams that had a velocity of less than 1.5 feet per second.

The samples for major ion and nutrient chemistry were filtered onsite through a disposable filter with a 0.45 -micrometer $(\mu \mathrm{m})$ pore size and analyzed by the DNREC laboratory in Dover, Delaware. Samples were analyzed for major ions by either the inductively coupled plasma method with atomic emission spectrometry, ion chromatography, or automated colorimetry. Nutrient analyses were performed by automated colorimetry (with persulfate digestion when required) with uncertainties of less than 10 percent (less than 20 percent for silica) (Ben Pressly, DNREC, written commun., 2012).

Samples collected for analysis of nitrogen isotopes were filtered onsite using a sterile Nalgene nitrate-free 0.2-millimeter (mm) filter, frozen until shipped to the USGS Stable Isotope Laboratory in Reston, Virginia, and analyzed using the bacterial reduction method (Sigman and others, 2001; Casciotti and others, 2002). The nitrogen isotopic delta $\left(\delta^{15} \mathrm{~N}\right)$ values obtained represent the isotopic ratio of ${ }^{15} \mathrm{~N} /{ }^{14} \mathrm{~N}$ of the sample relative to the standard of atmospheric $\mathrm{N}_{2}$, whereas $\delta^{18} \mathrm{O}$ values represent the isotopic ratio of ${ }^{18} \mathrm{O} /{ }^{16} \mathrm{O}$ of the sample relative to the standard of Vienna Standard Mean Ocean Water. The isotopic ratios in this study are reported in parts per thousand (\%), normalized to reference values given in Böhlke and others (2003), with analytical uncertainties (1-sigma) of approximately $\pm 0.25 \%$ for $\delta^{15} \mathrm{~N}$ and $\pm 0.5 \%$ for $\delta^{18} \mathrm{O}$ (Révész and Casciotti, 2007).
Samples for age dating were processed, preserved, and shipped to the USGS Chlorofluorocarbon Laboratory in Reston, Virginia and the apparent age of groundwater was determined from concentrations of dissolved gases $\left(\mathrm{N}_{2}, \mathrm{Ar}\right.$, $\mathrm{CH}_{4}, \mathrm{O}_{2}, \mathrm{CO}_{2}$ ) and gaseous $\mathrm{SF}_{6}$ using methods described in Busenburg and Plummer (1992). $\mathrm{SF}_{6}$ is soluble in groundwater, and the increasing rate of anthropogenic concentrations of $\mathrm{SF}_{6}$ has been well established for the atmosphere over time. Detectable amounts of $\mathrm{SF}_{6}$ are often present in younger waters (approximately 1970s) such as the surficial aquifer of Bucks Branch, and can be used for age dating. The apparent age of groundwater reflects atmospheric concentrations of $\mathrm{SF}_{6}$ at the time the water reached the water table.

The quality assurance of sampling included both replicate and blank samples. There was no significant variability or bias apparent in the sampling or laboratory techniques for the major ions, nutrients, nitrogen isotopes, or age dating. An internal USGS laboratory evaluation program (LEP) was completed for the major ions and nutrient samples analyzed by the DNREC laboratory, from which a comparison and analysis of recent standard reference samples were performed. The ion balance was calculated to check the analytical results, and was considered to be of good quality (Hem, 1985). The LEP was approved for the objectives of this report and entry of the data into the USGS National Water Information System (NWIS). After results were received from the laboratories, graphical and statistical analyses using relative abundance patterns, trilinear diagrams, correlation matrices, and linear correlations were generated to describe the data collected.

\section{Estimated Residence Time of Groundwater}

The apparent age of groundwater sampled in the Bucks Branch watershed during June 2011 ranged from 13 to 30 years, with a median age of 18 years (table 1). This range is similar to groundwater ages reported for other areas of the Delmarva Coastal Plain (Dunkle and others, 1993). Wells were selected randomly throughout the watershed and most wells had long screened intervals that intercept flow paths of varying ages; therefore, no clear relation between apparent age and well depth was observed. Since the samples are likely to be mixed, the apparent ages may not be equal to the actual mean ages of the samples; nevertheless, the aggregated data are considered to indicate the approximate residence time of groundwater in the surficial aquifer.

The residence time of groundwater contributing to the stream during base flow was based on an empirical model using simple linear regression of groundwater ages and silica concentrations in groundwater within the Bucks Branch watershed (fig. 4). Similar relations have been shown to be useful surrogates for age on the local scale throughout parts of the Atlantic Coastal Plain because concentrations of silica increase over time as minerals containing silica, including 
Table 1. Minimum, median, and maximum values of selected characteristics and constituents in groundwater and surface-water samples collected synoptically in the Bucks Branch watershed, Sussex County, Delaware, spring and summer 2011.

[ft, feet; $\mathrm{ft} / \mathrm{s}$, cubic feet per second; ${ }^{\circ} \mathrm{C}$, degrees Celsius; $\mu \mathrm{S} / \mathrm{cm}$, microsiemens per centimeter; $\mathrm{mg} / \mathrm{L}$, milligrams per liter; $\mu \mathrm{g} / \mathrm{L}$, micrograms per liter; min, minimum; max, maximum; n, number of samples; <, less than; --, no data; $\mathrm{N}$, nitrogen $\mathrm{CaCO}_{3}$, calcium carbonate; $\mathrm{NO}_{3}$, nitrate, laboratory; nitrogen isotopic delta $\left(\delta^{15} \mathrm{~N}\right)$ values of nitrate represent the isotopic ratio of ${ }^{15} \mathrm{~N} /{ }^{14} \mathrm{~N}$ of the sample relative to the standard of atmospheric $\mathrm{N}_{2}$; oxygen isotopic delta $\left(\delta^{15} \mathrm{O}\right)$ values of nitrate represent the isotopic ratio of ${ }^{18} \mathrm{O} /{ }^{16} \mathrm{O}$ of the sample relative to the standard of Vienna Standard Mean Ocean Water]

\begin{tabular}{|c|c|c|c|c|c|c|c|c|c|}
\hline \multirow{3}{*}{ Constituent (units) } & \multicolumn{3}{|c|}{ Groundwater } & \multicolumn{6}{|c|}{ Surface water } \\
\hline & \multicolumn{3}{|c|}{$\begin{array}{c}\text { June } 2011 \\
(n=10)\end{array}$} & \multicolumn{3}{|c|}{$\begin{array}{l}\text { High base flow } \\
\text { March } 2011 \\
(n=7)\end{array}$} & \multicolumn{3}{|c|}{$\begin{array}{c}\text { Low base flow } \\
\text { August } 2011 \\
(n=5)\end{array}$} \\
\hline & Min & Median & Max & Min & Median & Max & Min & Median & Max \\
\hline \multicolumn{10}{|c|}{ Physical properties } \\
\hline Temperature $\left({ }^{\circ} \mathrm{C}\right)$ & 14.7 & 16.0 & 17.0 & 7.1 & 13.1 & 14.0 & 20.0 & 22.9 & 23.8 \\
\hline Specific conductance $\left(\mu \mathrm{S} / \mathrm{cm}\right.$ at $\left.25^{\circ} \mathrm{C}\right)$ & 76 & 144 & 544 & 147 & 175 & 219 & 120 & 196 & 220 \\
\hline Dissolved oxygen (mg/L) & 2.3 & 4.8 & 9.9 & 10.1 & 13.3 & 17.0 & 5.4 & 7.0 & 8.0 \\
\hline $\mathrm{pH}$ (standard units) & 4.8 & 5.0 & 5.4 & 6.0 & 6.2 & 6.5 & 6.4 & 6.5 & 6.9 \\
\hline Ammonia (mg/L as $\mathrm{N})$ & $<0$ & 0.01 & 0.03 & $<0.01$ & 0.01 & 0.18 & 0.06 & 0.14 & 0.16 \\
\hline Phosphorus (mg/L) & 0.01 & 0.01 & 0.02 & 0.01 & 0.02 & 0.03 & 0.02 & 0.04 & 0.09 \\
\hline \multicolumn{10}{|c|}{ Major ions or elements } \\
\hline Calcium (mg/L) & 3.0 & 13.1 & 51.2 & 9.3 & 11.9 & 15.6 & 13.7 & 17.3 & 19.5 \\
\hline Magnesium (mg/L) & 0.7 & 3.2 & 14.9 & 2.4 & 3.7 & 5.6 & 4.3 & 5.4 & 6.9 \\
\hline Potassium (mg/L) & 1.3 & 3.5 & 9.0 & 2.2 & 2.6 & 3.2 & 3.6 & 3.7 & 4.2 \\
\hline Sodium (mg/L) & 3.6 & 8.0 & 16.9 & 8.7 & 9.1 & 9.7 & 9.2 & 9.7 & 9.9 \\
\hline Bicarbonate (mg/L) & 2.5 & 7.1 & 14.6 & 10.7 & 11.6 & 14.0 & 28.9 & 29.9 & 36.5 \\
\hline Chloride (mg/L) & 6.0 & 14.0 & 31.0 & 14.0 & 15.0 & 17.0 & 13.0 & 14.0 & 15.0 \\
\hline$\delta^{15} \mathrm{~N}\left(\right.$ per mil in $\mathrm{NO}_{3}$ ) & 1.4 & 5.7 & 13.4 & 6.5 & 7.7 & 10.4 & 9.3 & 10.5 & 11.9 \\
\hline$\delta^{18} \mathrm{O}\left(\right.$ per mil in $\left.\mathrm{NO}_{3}\right)$ & 1.1 & 2.3 & 5.7 & 3.4 & 3.9 & 5.7 & 5.2 & 6.1 & 6.5 \\
\hline \multicolumn{10}{|c|}{ Dissolved gases } \\
\hline Argon $(\mathrm{mg} / \mathrm{L})$ & 0.7 & 0.7 & 0.8 & -- & -- & -- & -- & -- & -- \\
\hline Carbon dioxide (mg/L) & 23.3 & 41.7 & 95.8 & -- & -- & -- & -- & -- & -- \\
\hline Dissolved oxygen, lab (mg/L) & 2.4 & 5.1 & 9.5 & -- & -- & -- & -- & -- & -- \\
\hline Methane (mg/L) & 0.0 & 0.0 & 0.0 & -- & -- & -- & -- & -- & -- \\
\hline Nitrogen gas $(\mathrm{mg} / \mathrm{L})$ & 16.8 & 20.2 & 23.8 & -- & -- & -- & -- & -- & -- \\
\hline \multicolumn{10}{|c|}{ Residence time } \\
\hline Estimated age (years) & 13 & 18 & 30 & 13 & 19 & 21 & 21 & 22 & 26 \\
\hline
\end{tabular}




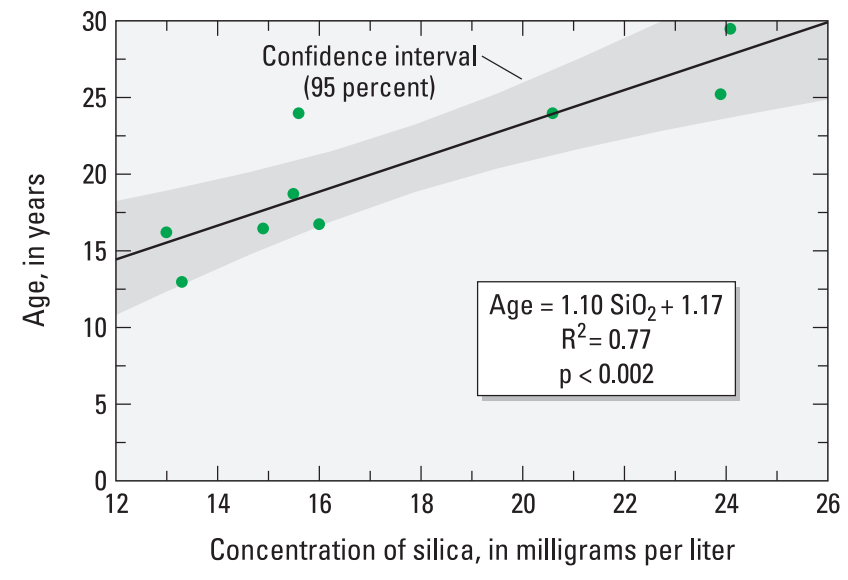

Figure 4. Concentration of silica in relation to the age of groundwater in Bucks Branch watershed, Sussex County, Delaware.

quartz and feldspars, are dissolved by water flowing through the groundwater system (Denver, 1986; Denver and others, 2010). A surface-water sample collected at base flow at a particular point in the stream system represents an aggregate of all groundwater discharging from upstream of that point in the watershed. A preliminary estimate of the aggregate residence time of groundwater contributing to surface-water samples can be made by comparing concentrations of silica in surface water to the data shown in figure 4. Using this method, the aggregate groundwater residence times contributing to streamflow range from 13 to 26 years (table 1). The estimated residence time of groundwater contributing to streamflow for the entire Bucks Branch watershed represented by data at the outlet (SW1; fig. 1), is approximately 19 years. This value is comparable to the overall median age (18 years) for groundwater. Surface-water samples were not available in Gilbert Trivitis Ditch; therefore, the groundwater sample from this subwatershed was not used for calculating the age of surface water. These estimates might be refined with more explicit consideration of mixing effects on the concentrations of silica and age tracers, but that was beyond the scope of this study.

Shallow groundwater flow paths can influence the age of surface water both temporally and spatially (Lindsey and others, 2003). The estimated ages of stream water are younger during high base flow (March) than low base flow (August) (table 1). This observation is consistent with the stream having received more contributions from shallow flow paths containing water with shorter residence times when the water table was higher in the spring. Although the median ages of groundwater and surface water were similar, the median age of all surface-water samples (20 years) was slightly older than the median age of groundwater samples (18 years), possibly because the aggregate groundwater contributing to streamflow included older water that was not intercepted in the domestic wells (table 1, fig. 5H).

\section{Chemical and Isotopic Analysis of Nitrate}

The isotopic analysis of nitrate along with the major-ion chemistry of the groundwater and surface water provided useful insight into the sources of nitrogen and a better understanding of the biogeochemical processes that occur in the Bucks Branch watershed. The geochemical characteristics of the surficial aquifer are presented through summary statistics of the water quality, correlations of nitrate with other major constituents and a graphical representation of the type of water found in this setting. The nitrogen and oxygen isotopes of nitrate are compared with those from previous studies and the pattern of isotopic enrichment of nitrate in the groundwater and surface water is discussed in the following sections.

\section{Major-Ion Chemistry}

Under natural conditions, dissolved ions in the groundwater of the surficial aquifer are derived largely from atmospheric deposition and dissolution of silicate minerals (Denver, 1986). This results in dilute acidic groundwater in which sodium, bicarbonate, and chloride are the major ions and concentrations of nitrate are less than 1 milligram per liter $(\mathrm{mg} / \mathrm{L})$ as $\mathrm{N}$ (table 2). The surficial aquifer in the Bucks Branch watershed is susceptible to contamination because of the combination of well-drained soils, sandy aquifer sediments, and a shallow water table. As a result, constituents from chemicals applied to enhance crop production in excess of plant needs are present in groundwater and concentrations of ions are generally much greater than those present under natural conditions (table 1, fig. 5).

In the wells sampled in this study, the surficial aquifer had oxic conditions with dissolved oxygen levels greater than $0.5 \mathrm{mg} / \mathrm{L}$ (McMahon and Chapelle, 2007). Microbes will utilize nitrate as an energy source only if free oxygen is not available (Drever, 1997). The lack of these reducing conditions for effective removal of nitrate by microbes coupled with the high rate of nitrogen input often leaves any effects of possible attenuation of nitrate indistinguishable in the surficial aquifer (Böhlke and Denver, 1995). Nitrate concentrations exceeded the U.S. Environmental Protection Agency (USEPA) drinking-water standard $(10 \mathrm{mg} / \mathrm{L}$ as $\mathrm{N})$ in 60 percent of the groundwater wells and at 42 percent of the surface-water sites (fig. 5B) (U.S. Environmental Protection Agency, 2009).

In comparison to natural conditions, the $\mathrm{pH}$ was slightly more acidic, possibly as a result of nitrification of ammonia and organic nitrogen from fertilizer, manure, and soil organic matter (tables 1 and 2). For arable soil to remain fertile, the acidity is neutralized with the application of crushed dolomite $\left[\mathrm{CaMg}\left(\mathrm{CO}_{3}\right)_{2}\right]$, referred to locally as "lime." The dolomite applications are reflected in the groundwater by the increased levels of calcium $\left(\mathrm{Ca}^{2+}\right)$ and magnesium $\left(\mathrm{Mg}^{2+}\right)$ ions and their significant relation with nitrate (table 1, fig. 6A). The 

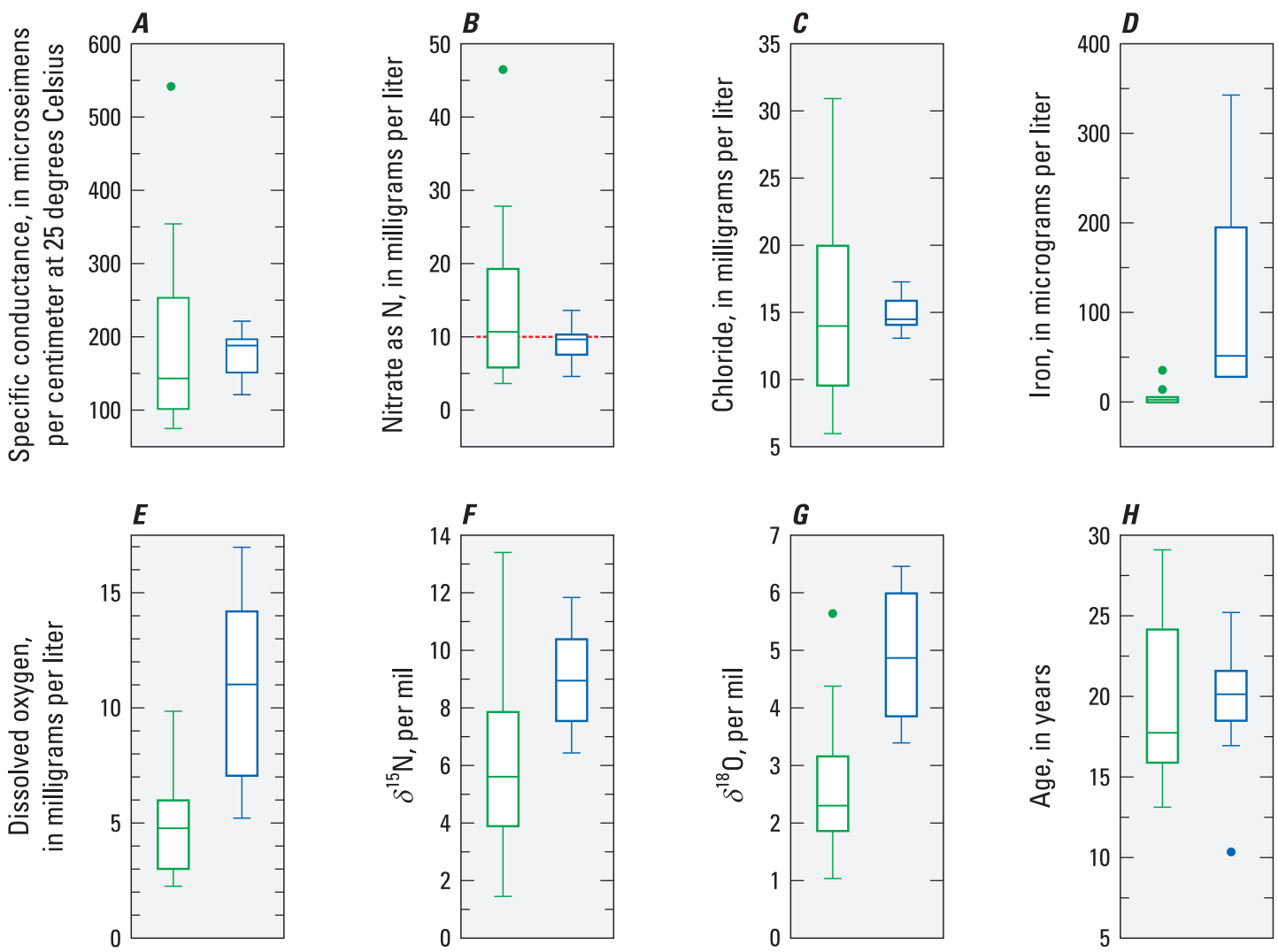

\section{EXPLANATION}

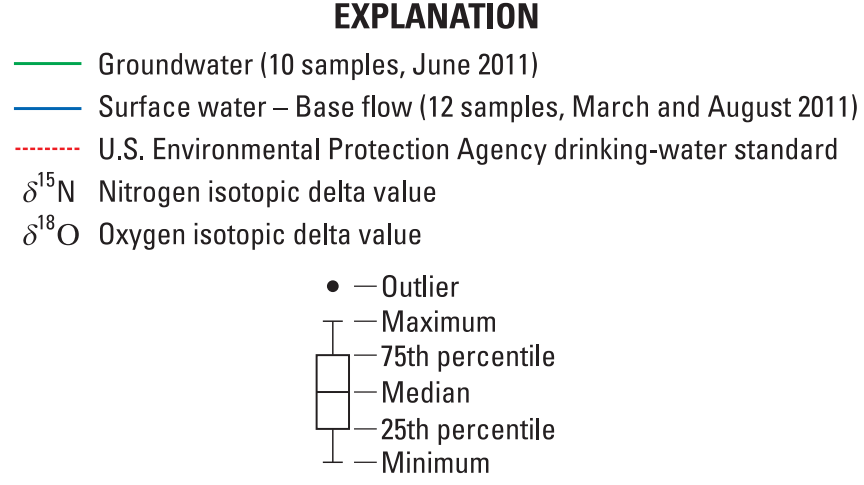

Figure 5. Distribution of selected characteristics and constituents in groundwater and surface-water samples, Bucks Branch watershed, Sussex County, Delaware.

plant nutrient potash $(\mathrm{KCl})$ that is applied to agricultural soils results in elevated levels of potassium $\left(\mathrm{K}^{+}\right)$and chloride $\left(\mathrm{Cl}^{-}\right)$ ions in groundwater and also has a significant relation with nitrate (table 1, fig. 6B).

Specific conductance was a good predictor of nitrate concentrations in the Bucks Branch watershed because the overall ionic strength in groundwater is dominated by ions that are commonly related to agricultural applications of fertilizer, manure, and lime (fig. 6C). The specific conductance intercept of 34.5 microsiemens per centimeter $(\mu \mathrm{S} / \mathrm{cm})$ is comparable to what would be expected under natural conditions (Denver, 1986; Denver and others, 2010) (fig. 6C).
Median concentrations of chloride and other ions that are not affected by reducing conditions (calcium, magnesium, potassium, and sodium) were similar in groundwater and surface water. The range of these values is greater in groundwater than in surface water because surface water is a mixture of all the groundwater flow paths discharging from the upstream watershed (table 1).

Concentrations of nitrate, iron, and dissolved oxygen are potentially affected by geochemical conditions and differed in groundwater and surface-water environments (figs. 5B, D, E). The differences are most likely related to changes in water chemistry that occur as discharging groundwater flows through 
Table 2. Chemistry of natural groundwater in the surfical aquifer of Southern Delaware.

$[\mu \mathrm{S} / \mathrm{cm}$, microsiemens per centimeter; $\mathrm{mg} / \mathrm{L}$, milligrams per liter]

\begin{tabular}{lc}
\hline \multicolumn{1}{c}{ Chemical constituent } & Median value $^{1}$ \\
\hline Silica & $23 \mathrm{mg} / \mathrm{L}$ \\
\hline Specific conductance & $55 \mu \mathrm{S} / \mathrm{cm}$ \\
$\mathrm{pH}$ & 5.8 \\
\hline Bicarbonate & $15.6 \mathrm{mg} / \mathrm{L}$ \\
\hline Calcium & $2.6 \mathrm{mg} / \mathrm{L}$ \\
\hline Magnesium & $0.6 \mathrm{mg} / \mathrm{L}$ \\
\hline Potassium & $1.2 \mathrm{mg} / \mathrm{L}$ \\
\hline Sodium & $6.7 \mathrm{mg} / \mathrm{L}$ \\
\hline Nitrate as N & $0.9 \mathrm{mg} / \mathrm{L}$ \\
Chloride & $5.4 \mathrm{mg} / \mathrm{L}$ \\
Sulfate & $1.1 \mathrm{mg} / \mathrm{L}$ \\
Iron & $0.03 \mathrm{mg} / \mathrm{L}$ \\
\hline
\end{tabular}

${ }^{1}$ Source: Denver, 1986, 1989.

near-stream riparian-zone sediments where it may encounter reducing conditions and increase concentrations of dissolved iron. When the discharging groundwater is reintroduced to the atmosphere in the stream, the dissolved oxygen increases. Higher concentrations of iron in surface water compared to groundwater provide evidence that some of the nitrate could be lost prior to discharge to the stream through denitrification if groundwater passed through the shallow riparian zone sediments. These effects were more apparent in the summer (August) during low base flow than in the spring (March) during high base flow.

Besides inputs of nitrogen from local land-use sources, a combination of factors contribute to high concentrations of nitrate in surface water all year. The thick surficial aquifer in the Bucks Branch watershed and ditching of stream channels has potentially disconnected much of the stream network from the riparian zone. As a result, many groundwater flow paths containing high concentrations of nitrate may bypass the anoxic conditions associated with the riparian zone and discharge directly through the sandy streambed.

Overall, the groundwater and surface water under natural settings reflect a $\mathrm{Ca}-\mathrm{Na}-\mathrm{HCO}_{3}$ water type compared to the agricultural $\mathrm{Ca}-\mathrm{Mg}-\mathrm{NO}_{3}$ water type found in the Bucks Branch watershed (fig. 7). The relative abundance of cations and anions in groundwater and surface water present a pattern commonly seen in water affected by agriculture (figs. 7A and 7B) (Denver, 1989). Also, spatial and temporal differences are apparent in the chemical composition as groundwater moves to surface water during high and low base-flow conditions, as shown in the trilinear diagram in figure $7 \mathrm{C}$. The collective geochemistry in the Bucks Branch watershed is similar to the geochemistry described in other water-quality studies in the
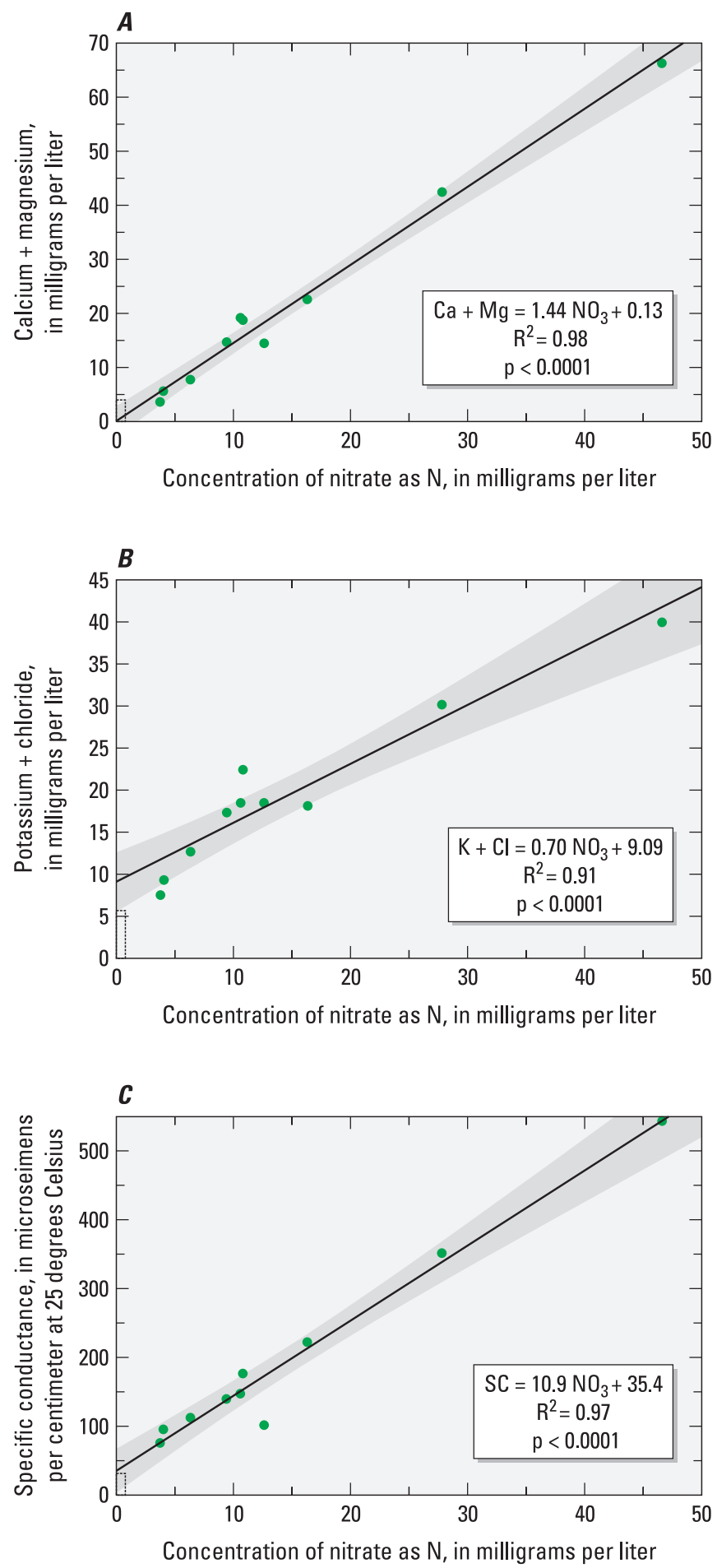

\section{EXPLANATION}

- Groundwater

Natural conditions (Denver, 1986, 1989)

Confidence interval (95 percent)

Figure 6. Concentrations of nitrate in relation to the concentrations of $(A)$ calcium plus magnesium $(\mathrm{Ca}+\mathrm{Mg}),(B)$ potassium plus chloride $(\mathrm{K}+\mathrm{Cl})$, and $(\mathrm{C})$ specific conductance (SC) in groundwater samples collected in Bucks Branch watershed, Sussex County, Delaware, 2011. 


\section{A Groundwater}

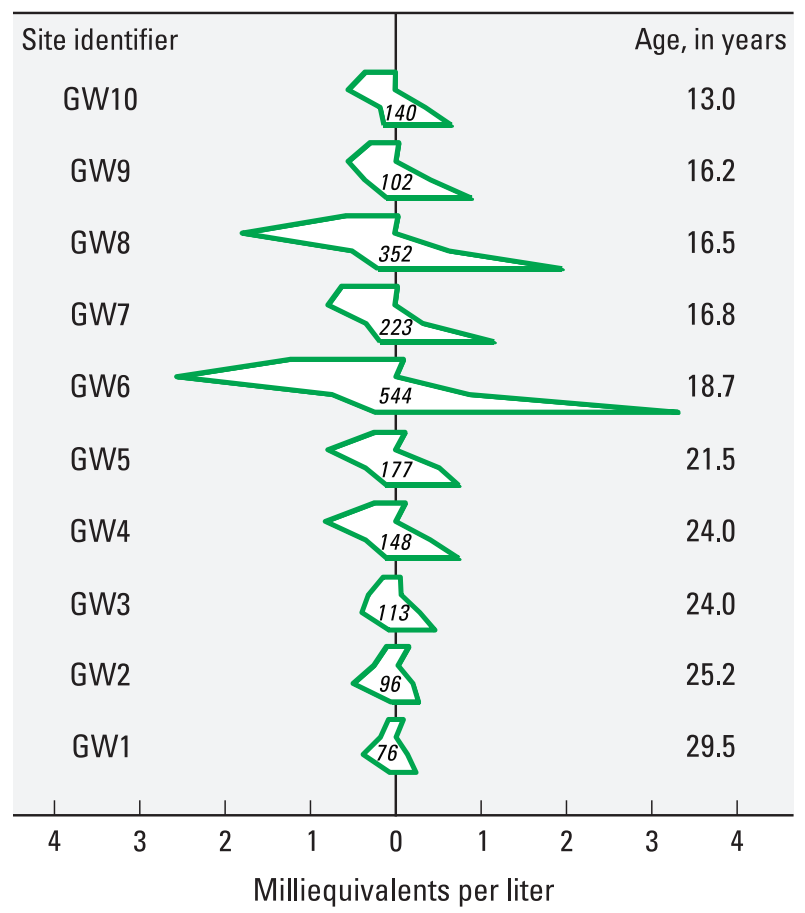

B Surface water

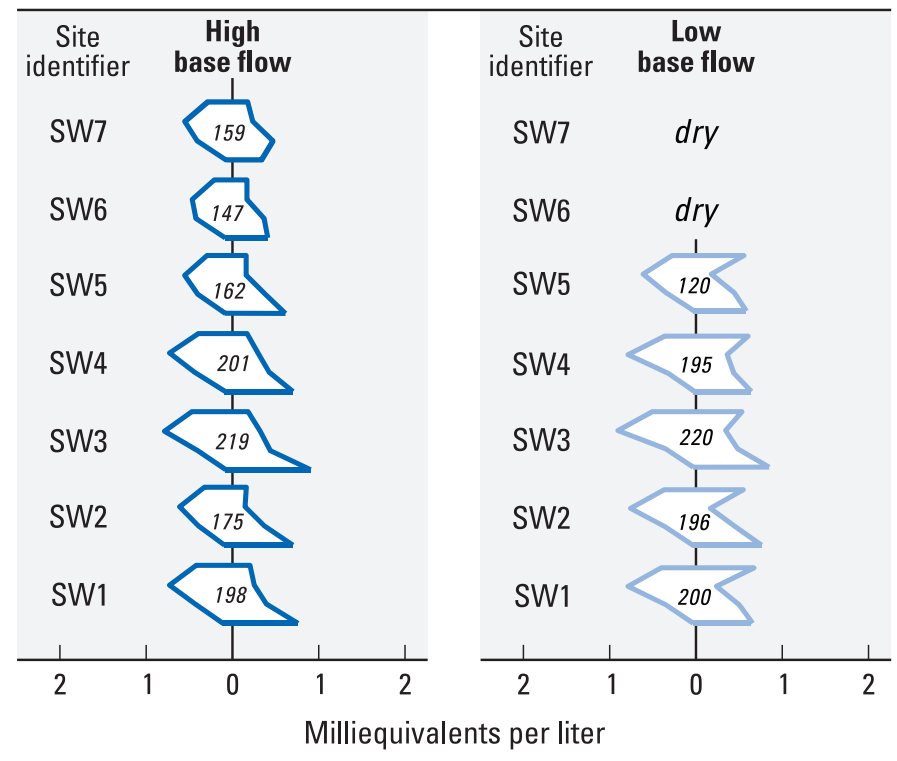

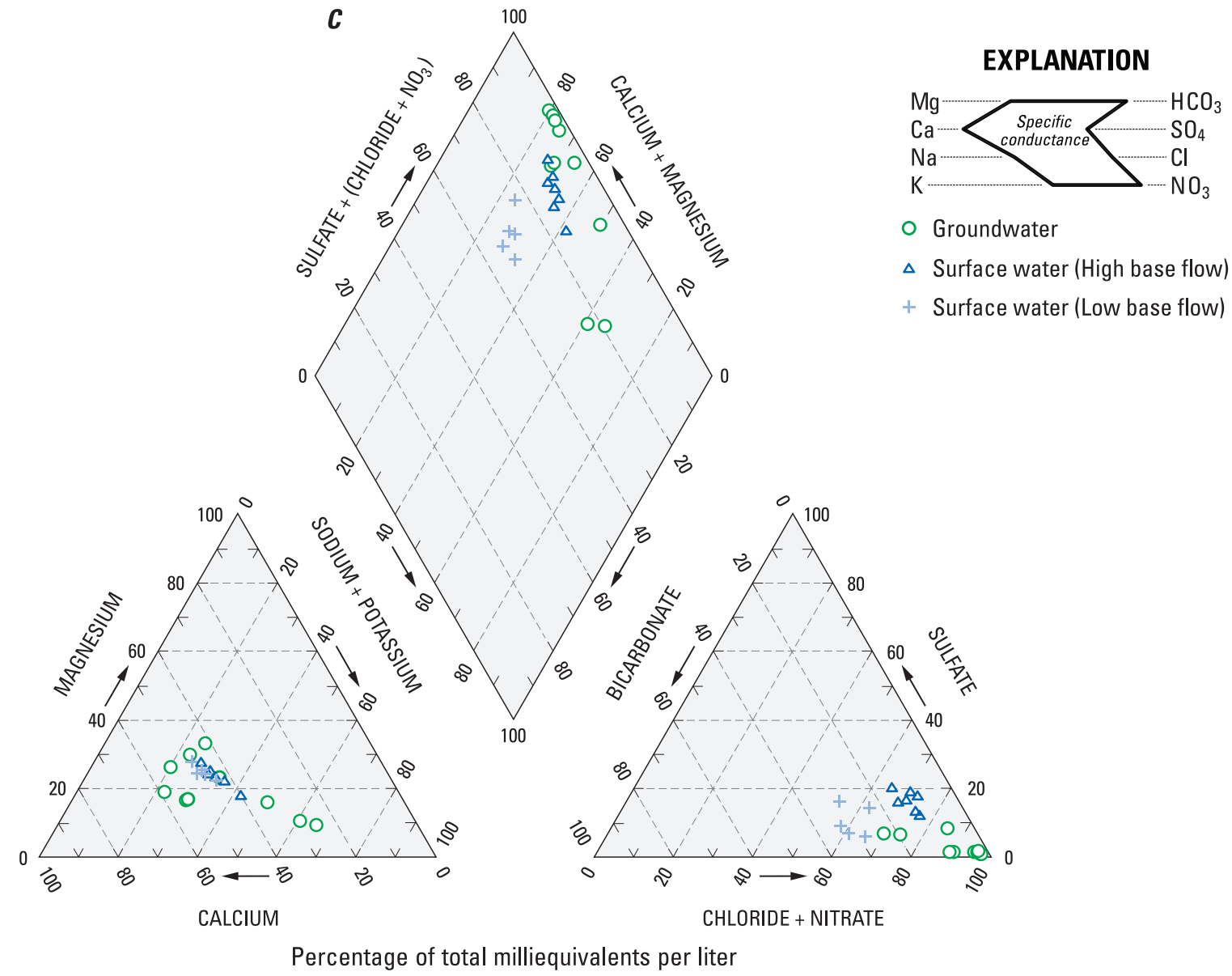

Figure 7. Relative abundance patterns of constituents in samples of $(A)$ groundwater and $(B)$ surface water, and $(C)$ a trilinear diagram of major ions within Bucks Branch watershed, Sussex County, Delaware. 
Delmarva Coastal Plain and is an indication that agriculture is the predominant source of nitrate contamination (Denver, 1986, 1989; Hamilton and others, 1993; Böhlke and Denver, 1995; Ator and others, 2004).

\section{Isotopic Composition of Nitrate}

The major sources of nitrogen in the Bucks Branch watershed, based on county estimates, are inorganic fertilizer, manure, and atmospheric deposition (Ruddy and others, 2006) (fig. 3). Most of the $\delta^{15} \mathrm{~N}$ values of nitrate in groundwater shown in figure 8 are similar to those commonly reported for nitrate recharged beneath natural soils or fertilized fields with values around +2 to $+6 \%$ (Heaton, 1986; Böhlke and others, 2002). The $\delta^{15} \mathrm{~N}$ values of nitrate in groundwater samples were lower than those in the stream-water samples collected during base flow (fig. 5F, table 1). Surface water at base flow represents the cumulative contributions of upstream groundwater recharged from all possible sources of natural soil, fertilized soil, and manure/septic areas, and any geochemical changes (figs. 8 and 9). Although the $\delta^{15} \mathrm{~N}$ values from surface water at base flow were similar to data observed for nitrate recharged beneath manure/septic areas $(+8$ to $+20 \%)$, the major-ion chemistry of groundwater and surface water described in the previous section provides evidence that $\delta^{15} \mathrm{~N}$ enrichment is more likely from the loss of nitrate through denitrification
(Kreitler and Jones, 1975; Gormly and Spalding, 1979; Böhlke and others, 2002).

Further evidence for denitrification as an important process affecting the differences in isotopic composition of groundwater and surface water is seen in the comparison of the nitrogen and oxygen isotopes of nitrate. Denitrification converts $\mathrm{NO}_{3}$ to $\mathrm{N}_{2}$ gas and the microbial preference of lighter isotopes $\left({ }^{14} \mathrm{~N}\right.$ and $\left.{ }^{16} \mathrm{O}\right)$ during this isotope fractionation leaves the residual $\mathrm{NO}_{3}$ more enriched in heavier isotopes $\left({ }^{15} \mathrm{~N}\right.$ and ${ }^{18} \mathrm{O}$ ) and the lighter molecules escape into the vapor phase (Kendall and McDonnell, 1998; Eby, 2004). An enrichment trend of the heavier isotopes in nitrate is shown in figure 8 with a 2:1 slope of $\delta^{15} \mathrm{~N}$ to $\delta^{18} \mathrm{O}$. One groundwater sample is not shown because of degassing during shipment. This linear relation between the $\mathrm{N}$ and $\mathrm{O}$ isotopes in flow-path studies has been shown to be an indication of denitrification in groundwater (Böttcher and others, 1990; Groffman and others, 2006). Although the samples collected from Bucks Branch are not along a flow path, the values of $\delta^{18} \mathrm{O}$ observed in the stream samples also indicate denitrification, because they are higher than typical $\delta^{18} \mathrm{O}$ values of nitrate formed by nitrification in this region ( +1 to $+3 \%$ ) (J.K. Böhlke, U.S. Geological Survey, written commun., 2012). Excess $\mathrm{N}_{2}$ gas produced by denitrification was also detected in three of the groundwater samples indicating denitrification is also possible in some parts of the groundwater system prior to reaching stream discharge areas.

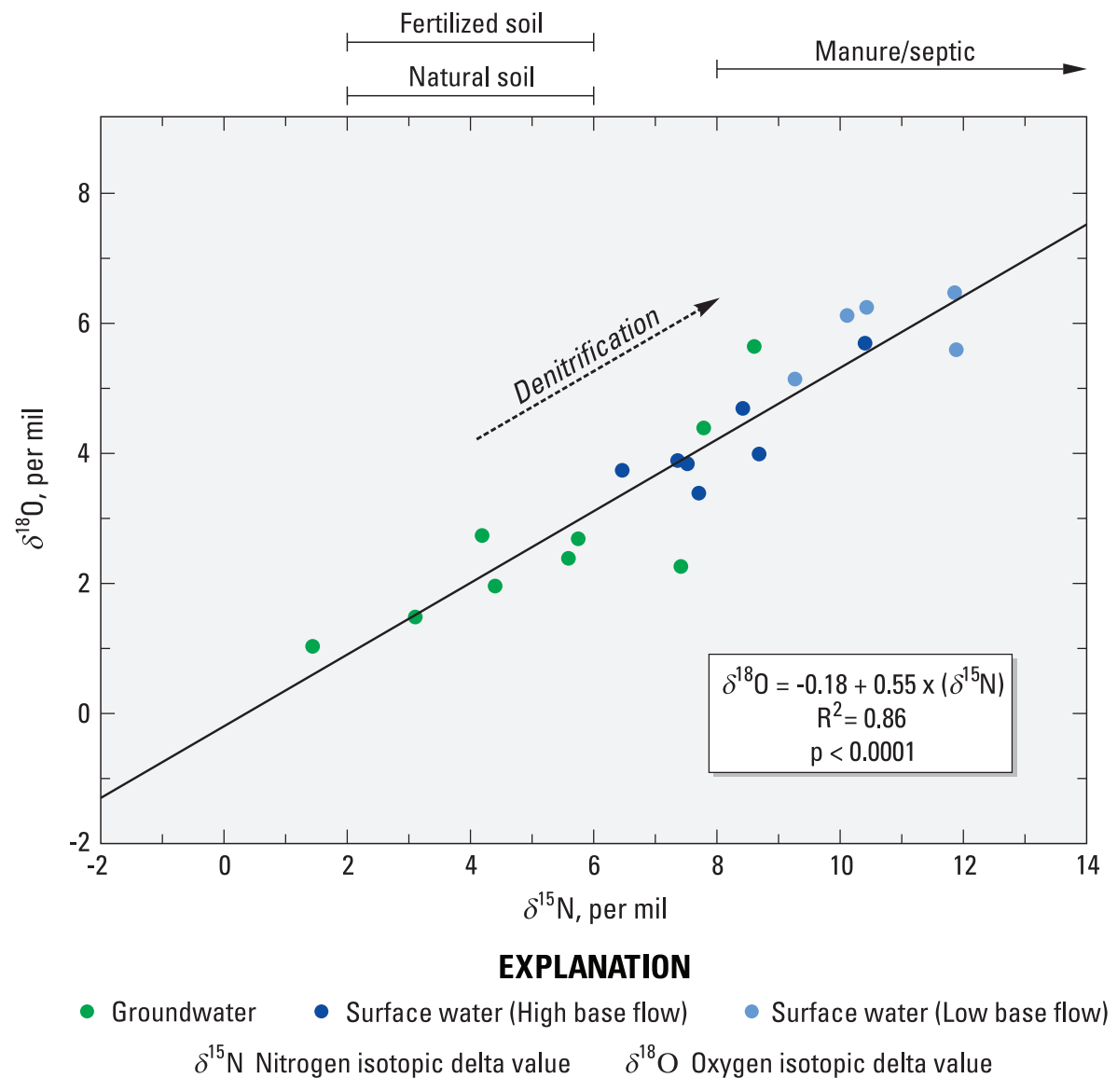

Figure 8. Relation of nitrogen isotopes to oxygen isotopes in groundwater and surface water, Bucks Branch watershed, Sussex County, Delaware (Heaton, 1986; Böhlke and others, 2002). 


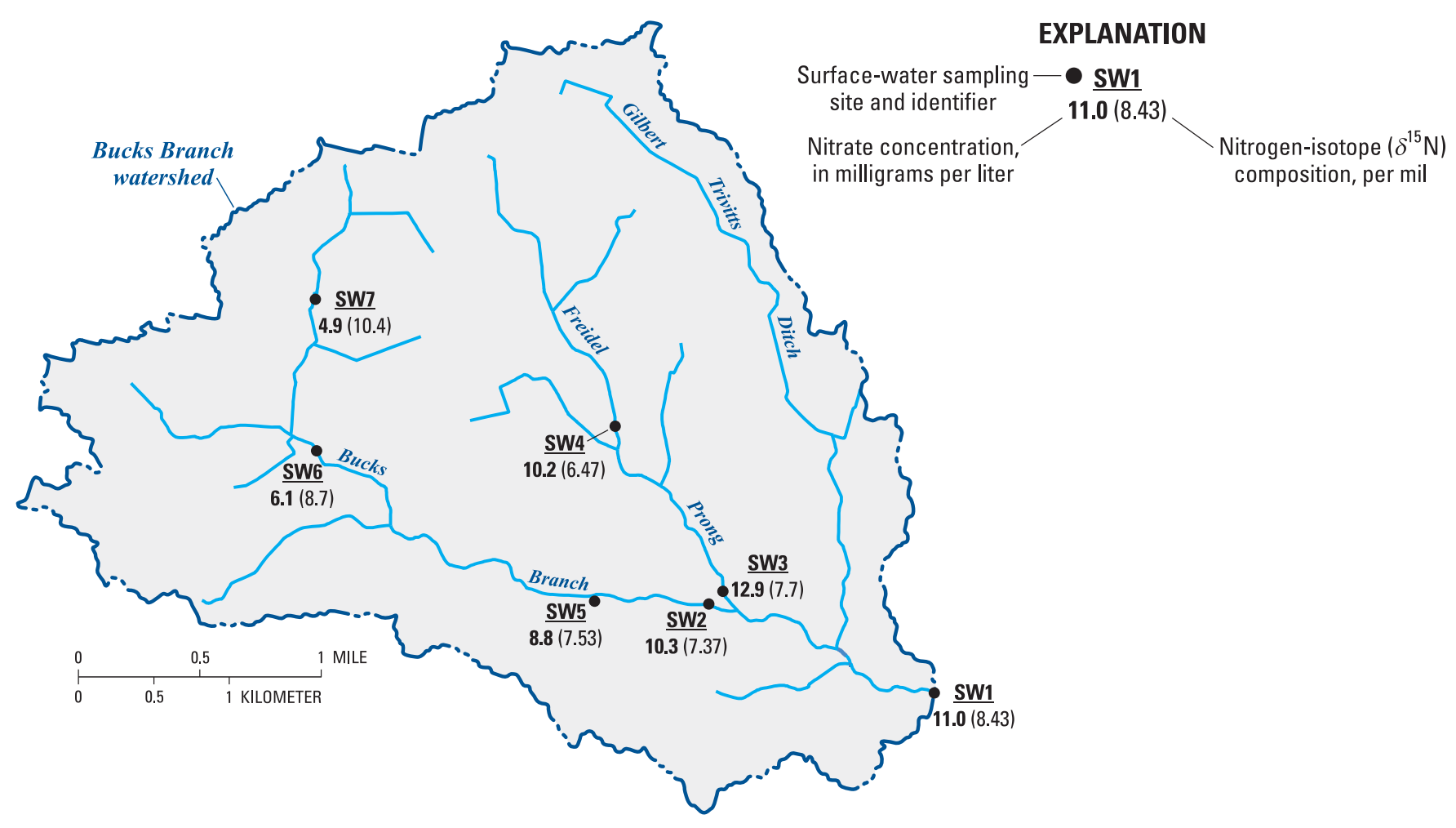

Figure 9. Nitrate concentrations and nitrogen-isotope compositions in samples of surface water collected synoptically during high base-flow conditions, Bucks Branch watershed, Sussex County, Delaware, March 2011.

\section{Summary and Conclusions}

Bucks Branch in Sussex County, Delaware has some of the highest concentrations of total nitrogen measured in any stream in the State. Analysis of major-ion chemistry, the isotopic composition of nitrate, and age-dating techniques were used to improve the understanding of the chemical and isotopic composition of nitrate in the groundwater in this watershed and provide a range for the residence time of groundwater in the surficial aquifer. Land use in the Bucks Branch watershed is predominantly agricultural and nitrate concentrations exceeded the U.S. Environmental Protection Agency drinkingwater standard (10 milligrams per liter as nitrogen) in samples from 60 percent of the groundwater wells and 42 percent of the surface-water sites used in this study. Results of analysis of the geochemistry of groundwater and surface water indicates that agriculture is the predominant source of nitrate contamination. The pattern of enrichment in nitrogen and oxygen isotopes $\left(\delta^{15} \mathrm{~N}\right.$ and $\left.\delta^{18} \mathrm{O}\right)$ in groundwater and surface water is consistent with loss of nitrate through denitrification, but rates of denitrification were not sufficient to remove most of the nitrate from groundwater discharging to streams. The estimated aggregate residence time of groundwater contributing to surface water for the entire Bucks Branch watershed in the most downstream sample is approximately 19 years. Further study along specific groundwater flow paths could lead to a better understanding of the rate of denitrification, the relative importance of fertilizer and manure sources, and the influence of shallow groundwater on stream quality. The preliminary analysis in this report provides information about the transport and fate of nitrate in small scale watersheds that can be useful for better management of agriculture and water resources.

\section{Acknowledgments}

This project was funded under a cooperative agreement between the Delaware Geological Survey (DGS) and the U.S. Geological Survey (USGS), in support of the Delaware Department of Natural Resources and Environmental Control (DNREC).

The authors would like to thank Hassan Mirsajadi, Amber Joseph, Blair Venables, Xie Xia, Kathy Knowles, Sergio Huerta, and Ben Pressly of DNREC for overall project support. Thanks are extended to Dr. Joanna York of the University of Delaware, and Deborah Bringman, Christopher Lewis, John Karl Böhlke, Scott Ator, Brook Connors, Douglas Chambers, Bruce Lindsey, Valerie Gaine, Timothy Auer, and Ruth Larkins of USGS for their assistance with this study. The authors also sincerely appreciate the generosity of local landowners who provided access for sampling. 


\section{References Cited}

Andres, A.S., 1994, Geohydrology of the Seaford area, Delaware: Delaware Geological Survey, Hydrologic Map No. 9, 1:24,000.

Ator, S.W., Brakebill, J.W., and Blomquist, J.D., 2011, Sources, fate, and transport of nitrogen and phosphorus in the Chesapeake Bay watershed: An empirical model: U.S. Geological Survey Scientific Investigations Report 20115167, 27 p. (also available online at http://pubs.usgs.gov/ sir/2011/5167/).

Ator, S.W., Denver, J.M., and Brayton, M.J., 2004, Hydrologic and geochemical controls on pesticide and nutrient transport to two streams on the Delmarva Peninsula: U.S. Geological Survey Water-Resources Investigations Report 2004-5051, 34 p. (also available online at http://pubs.usgs.gov/ sir/2004/5051/SIR2004-5051.pdf).

Ator, S.W., and Ferrari, M.J., 1997, Nitrate and selected pesticides in ground water of the Mid-Atlantic region: U.S. Geological Survey Water-Resources Investigations Report 97-4139, 8 p.

Böhlke, J.K., 2003, Sources, transport, and reaction of nitrate, in Lindsey, B.D., Phillips, S.W., Donnelly, C.A., Speiran, G.K., Plummer, L.N., Böhlke, J.K., Focazio, M.J., Burton, W.C., and Busenberg, E., 2003, Residence times and nitrate transport in ground water discharging to streams in the Chesapeake Bay watershed: U.S. Geological Survey WaterResources Investigations Report 03-4035, 201 p.

Böhlke, J.K., and Denver, J.M., 1995, Combined use of groundwater dating, chemical, and isotopic analyses to resolve the history and fate of nitrate contamination in two agricultural watersheds, Atlantic Coastal Plain, Maryland: Water Resources Research, v. 31, no. 9, p. 2,319-2,339.

Böhlke, J.K., Mroczkowski, S.J., and Coplen, T.B., 2003, Oxygen isotopes in nitrate: new reference materials for 18O:17O:16O measurements and observations on nitratewater equilibration: Rapid Communications in Mass Spectrometry, v. 17, no. 16, p. 1,835-1,846 (also available online at http://onlinelibrary.wiley.com/doi/10.1002/ rcm.1123/abstract).

Böhlke, J.K., Wanty, R., Tuttle, M., Delin, G., and Landon, M., 2002, Denitrification in the recharge area and discharge area of a transient agricultural nitrate plume in a glacial outwash sand aquifer, Minnesota: Water Resources Research, v. 38, no. 7, p. 10.1-10.26.

Böttcher, J., Strebel, O., Voerkelius, S., and Schmidt, H.L., 1990, Using isotope fractionation of nitrate-nitrogen and nitrate-oxygen for evaluation of microbial denitrification in a sandy aquifer: Journal of Hydrology, v. 114, nos. 3-4, p. $413-424$.
Busenberg, E., and Plummer, L.N., 1992, Use of chlorofluorocarbons $(\mathrm{CCl} 3 \mathrm{~F}$ and $\mathrm{CCl} 2 \mathrm{~F} 2)$ as hydrologic tracers and age-dating tools: The alluvium and terrace system of central Oklahoma: Water Resources Research, v. 28, no. 9, p. $2,257-2,283$.

Casciotti, K.L., Sigman, D.M., Hastings, M., Böhlke, J.K., and Hilkert, A., 2002, Measurement of the oxygen isotopic composition of nitrate in seawater and freshwater using the denitrifier method: Analytical Chemistry, v. 74, no. 19, p. 4,905-4,912 (also available online at http://pubs.acs.org/ doi/abs/10.1021/ac020113w).

Clark, I.D., and Fritz, P., 1997, Environmental isotopes in hydrogeology: Boca Raton, Florida, CRC Press, 328 p.

Debrewer, L.M., Ator, S.W., and Denver, J.M., 2007, Factors affecting spatial and temporal variability in nutrient and pesticide concentrations in the surficial aquifer on the Delmarva Peninsula: U.S. Geological Survey Scientific Investigations Report 2005-5257, 56 p. (also available online at http://pubs.usgs.gov/sir/2005/5257).

Delaware Department of Natural Resources and Environmental Control (DNREC), 2010, State of Delaware 2010 Combined Watershed Assessment Report (305b) and Determination for the Clean Water Act Section 303(d) List of Water Needing TMDLs, $70 \mathrm{p}$.

Denver, J.M., 1986, Hydrogeology and geochemistry of the unconfined aquifer in west-central and southwestern Delaware: Delaware Geological Survey Report of Investigations No. 41, $100 \mathrm{p}$.

Denver, J.M., 1989, Effects of agricultural practices and septic-system effluent on the quality of water in the unconfined aquifer system in parts of eastern Sussex County, Delaware: Delaware Geological Survey Report of Investigations No. 45,66 p.

Denver, J.M., Tesoriero, A.J., and Barbaro, J.R., 2010, Trends and transformation of nutrients and pesticides in a coastal plain aquifer system, United States: Journal of Environmental Quality, v. 39, no. 1, p. 154-167.

Drever, J.I., 1997, The geochemistry of natural waters, 3d ed.: Upper Saddle River, New Jersey, Prentice Hall, 388 p.

Dubrovsky, N.M., Burow, K.R., Clark, G.M., Gronberg, J.M., Hamilton, P.A., Hitt, K.J., Mueller, D.K., Munn, M.D., Nolan, B.T., Puckett, L.J., Rupert, M.G., Short, T.M., Spahr, N.E., Sprague, L.A., and Wilber, W.G., 2010, The quality of our Nation's waters-Nutrients in the Nation's streams and groundwater, 1992-2004: U.S. Geological Survey Circular 1350, 174 p. (also available online at http://pubs.usgs.gov/ circ/1350/). 
Dunkle, S.A., Plummer, L.N., Busenberg, E., Phillips, P.J., Denver, J.M., Hamilton, P.A., Michel, R.L., and Coplen, T.B., 1993, Chlorofluorocarbons (CCl3F and $\mathrm{CCl} 2 \mathrm{~F} 2)$ as dating tools and hydrologic tracers in shallow groundwater of the Delmarva Peninsula, Atlantic Coastal Plain, United States: Water Resources Research, v. 29, no. 12, p. 3,837-3,860.

Eby, N.G., 2004, Environmental geochemistry: Belmont, California, Brooks/Cole Cengage Learning, 514 p.

Gormly, J.R., and Spalding, R.F., 1979, Sources and concentrations of nitrate-nitrogen in ground water of the Central Platte region, Nebraska: Ground Water, v. 17, no. 3, p. 291-301.

Groffman, P.M., Altabet, M.A., Böhlke, J.K., ButterbachBahl, K., David, M.B., Giblin, A.E., Kana, T.M., Nielsen, L.P., Firestone, M.K., and Voytek, M.A., 2006, Methods for measuring denitrification: diverse approaches to a difficult problem: Ecological Applications, v. 16, no. 6, p. 2,0912,122 (also available online at http://www.esajournals.org/ doi/pdf/10.1890/1051-0761\%282006\%29016\%5B2091\%3A MFMDDA\%5D2.0.CO\%3B2).

Hamilton, P.A., Denver, J.M., Phillips, P.J., and Shedlock, R.J., 1993, Water-quality assessment of the Delmarva Peninsula, Delaware, Maryland, and Virginia - Effects of agricultural activities on, and distribution of, nitrate and other inorganic constituents in the surficial aquifer: U.S. Geological Survey Open-File Report 93-40, 87 p.

Heaton, T.H.E., 1986, Isotopic studies of nitrogen pollution in the hydrosphere and atmosphere: A review: Chemical Geology: Isotope Geoscience Section, v. 59, p. 87-102.

Hem, J.D., 1985, Study and interpretation of the chemical characteristics of natural water: U.S. Geological Survey Water-Supply Paper 2254, 263 p.

Johnston, R.H., 1973, Hydrology of the Columbia (Pleistocene) deposits of Delaware-An appraisal of the regional water-table aquifer: Delaware Geological Survey Bulletin No. 19, 78 p.

Kendall, C., and McDonnell, J.J., 1998, Isotope Tracers in catchment hydrology: Amsterdam, Elsevier Science B.V., $839 \mathrm{p}$.

Kreitler, C.W., and Jones, D.C., 1975, Natural soil nitrate: The cause of the nitrate contamination of ground water in Runnels County, Texas: Ground Water, v. 13, no. 1, p. 53-62.
Lindsey, B.D., Berndt, M.P., Katz, B.G., Ardis, A.F., and Skach, K.A., 2009, Factors affecting water quality in selected carbonate aquifers in the United States, 1993-2005: U.S. Geological Survey Scientific Investigations Report 2008-5240, 117 p. (also available online at http://pubs.usgs. gov/sir/2008/5240/).

Lindsey, B.D., Phillips, S.W., Donnelly, C.A., Speiran, G.K., Plummer, L.N., Böhlke, J.K., Focazio, M.J., Burton, W.C., and Busenberg, E., 2003, Residence times and nitrate transport in ground water discharging to streams in the Chesapeake Bay watershed: U.S. Geological Survey WaterResources Investigations Report 03-4035, 201 p.

McMahon, P.B., and Chapelle, F.H., 2007, Redox processes and water quality of selected principal aquifer systems: Ground Water, v. 46, no. 2, p. 259-271.

Mueller, D.K., and Spahr, N.E., 2006, Nutrients in streams and rivers across the Nation-1992-2001: U.S. Geological Survey Scientific Investigations Report 2006-5107, 44 p.

National Research Council (NRC), 2011, Achieving nutrient and sediment reduction goals in the Chesapeake Bay: An evaluation of program strategies and implementation: Washington, D.C., The National Academies Press, 258 p.

Puckett, L.J., 1995, Identifying the major sources of nutrient water pollution: Environmental Science \& Technology, v. 29 , no. 9 , p. 408 A-414A.

Révész, K., and Casciotti, K., 2007, Determination of the $\delta\left({ }^{15} \mathrm{~N} /{ }^{14} \mathrm{~N}\right)$ and $\delta\left({ }^{18} \mathrm{O} /{ }^{16} \mathrm{O}\right)$ of nitrate in water: RSIL Lab Code 2900, chap. C17 of Révész, Kinga, and Coplen, Tyler B., eds., Methods of the Reston Stable Isotope Laboratory: U.S. Geological Survey Techniques and Methods, book 10, sec. C, chap. 17, 24 p.

Ruddy, B.C., Lorenz, D.L., and Mueller, D.K., 2006, Countylevel estimates of nutrient inputs to the land surface of the conterminous United States, 1982-2001: U.S. Geological Survey Scientific Investigations Report 2006-5012, 17 p. (also available online at http://pubs.usgs.gov/ sir/2006/5012/).

Shedlock, R.J., Denver, J.M., Hayes, M.A., Hamilton, P.A., Koterba, M.T., Bachman, L.J., Phillips, P.J., and Banks, W.S.L., 1999, Water-quality assessment of the Delmarva Peninsula, Delaware, Maryland, and Virginia-Results of investigations, 1987-91: U.S. Geological Survey WaterSupply Paper 2355-A, 41 p. 
Sigman, D.M., Casciotti, K.L., Andreani, M., Barford, C., Galanter, M., and Böhlke, J.K., 2001, A bacterial method for the nitrogen isotopic analysis of nitrate in seawater and freshwater: Analytical Chemistry, v. 73, no. 17, p. $4,145-4,153$.

Spahr, N.E., Dubrovsky, N.M., Gronberg, J.M., Franke, O.L., and Wolock, D.M., 2010, Nitrate loads and concentrations in surface-water base flow and shallow groundwater for selected basins in the United States, water years 1990-2006: U.S. Geological Survey Scientific Investigations Report 2010-5098, 39 p. (also available online at http://pubs.usgs. gov/sir/2010/5098/).

Stoner, J.D., Cowdery, T.K., and Puckett, L.J., 1997, Groundwater age dating and other tools used to assess land-use effects on water quality: U.S. Geological Survey WaterResources Investigations Report 97-4150, 6 p.

U.S. Bureau of the Census, 1993, 1990 Census of housing: Detailed housing characteristics: U.S. Department of Commerce, Economics, and Statistics Administration, CH-2-9, [variously paged].

U.S. Department of Agriculture, 2012, Custom soil resource report for Sussex County, Delaware, Bucks Branch: National Cooperative, created online on February 2, 2012 at http://websoilsurvey.nrcs.usda.gov/app/HomePage.htm.

U.S. Environmental Protection Agency, 2009, National Primary Drinking Water Regulations, U.S. Environmental Protection Agency Report EPA 816-F-09-004, 6 p., accessed June 25, 2012 at $h t t p: / / w w w . e p a . g o v / o g w d w / c o n s u m e r / p d f /$ mcl.pdf.

U.S. Geological Survey, variously dated, National field manual for the collection of water-quality data: U.S. Geological Survey Techniques of Water-Resources Investigations, book 9, chaps. A1-A9, available online at http://pubs.water.usgs. gov/twri9A.

Weller, D.E., Jordan, T.E., Sellner, K.G., Foreman, K.L., Shenk, K.E., Tango, P.J., Phillips, S.W., and Dubin, M.P., 2010, Small watershed monitoring designs: A report prepared for the Chesapeake Bay Program Scientific and Technical Advisory Committee (STAC): Annapolis, Maryland, STAC publication \#10-004, 18 p.

Williams, P., Whitfield, M., Biggs, J., Bray, S., Fox, G., Pascale, N., and Sear, D., 2004, Comparative biodiversity of rivers, streams, ditches and ponds in an agricultural landscape in Southern England: Biological Conservation, v. 15, no. 2, p. 329-341, DOI: 10.1016/S0006-3207(03)00153-8. 

Prepared by USGS West Trenton Publishing Service Center. Edited by Ruth M. Larkins.

Graphics and layout by Timothy W. Auer.

For additional information, contact:

Director, MD-DE-DC Water Science Center

U.S. Geological Survey

5522 Research Park Drive

Baltimore, MD 21228

or visit our Web site at: http://md.water.usgs.gov 
